\section{Internationalisation within liner shipping}

Shipping lines: examining sales network

An examination of the sales network structures of shipping lines

Günter Prockl and Aseem Kinra

Department of Operations Management, Copenhagen Business School, Frederiksberg, Denmark, and

Herbert Kotzab

University of Bremen, Germany and Othman Yeop Abdullah Graduate Schoolof Business, Universiti Utara Malaysia, Changlun, Malaysia

\begin{abstract}
Purpose - Container shipping is generally considered a global business. This truth may not hold from a single-company perspective. The companies' physical operation networks show that container carriers operate differently and follow different paths in their internationalisation development. Additionally, the degree of internationalisation, measured on the basis of sea-oriented operations, differs from that measured according to land-oriented front-end marketing and sales activities. The purpose of this study is to further examine the internationalisation patterns of shipping lines.
\end{abstract}

Design/methodology/approach - An examination of the front-end activities and the structures of leading container-shipping companies is conducted. The sales office networks of the sector's 20 largest companies worldwide (by twenty-foot equivalent unit capacity) are analysed as key indicators. The numbers of sales offices are measured by analysing the websites of the sample (20 companies), as well as annual reports and other publicly available data sources.

Findings - The findings show that not all shipping companies are international, by virtue of the industry. While it is difficult to observe differences in the overall patterns of the sales networks at a macro level, some companies differ in their activities. The data set also shows that market share and total capacity are not necessarily good indicators of a carrier's worldwide presence.

Research limitations/implications - This research is based on secondary data. Other important transactional and market-oriented considerations should be examined before drawing conclusions about the internationalisation of container-shipping companies and of the industry.

Originality/value - This paper contributes to the relevant existing research, particularly by adding its view on the demand-oriented criteria as suggested by Dunning and Lundan (2008).

Keywords Internationalization, Container shipping, Shipping, Sales networks

Paper type Research paper

\section{Introduction}

International logistics is a broad field of study that focuses on the connection and the coordination roles of shipping and other logistic service providers in international trade (Wood, 2002). Liner shipping, along with the related services provided by the carriers, is an important component of international trade. When measured in volume, over 90

(C) Pacific Star Group Education Foundation

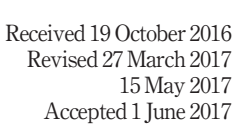

15 May 2017
Accepted 1 June 2017

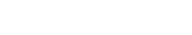


MABR

2,3

280

per cent of world trade today is conveyed by sea (International Chamber of Shipping, 2017). Levinson (2006) illustrates how the "shipping container made the world smaller and the world economy bigger", and Donovan and Bonney (2006) write about the "box that changed the world". Heaver (2002) emphasises this evolving and important role of shipping in this environment of international logistics and concludes that shipping lines are under pressure to further internationalise, develop and expand the geographical reach of their services.

Accordingly, McCalla et al. (2004) claim that back in 1989, most of the carriers were best characterised as regionally concentrated companies, operating on range-to-range services between ports on the East-West trades. In 2004, the authors observed these market differences diminishing; companies were serving most market areas in the world and showing far greater conformity in market coverage in 1999 than in 1989.

There is little reason to doubt the globalised shipping business as such. However, this paper updates and perhaps challenges McCalla et al.'s (2004) observation regarding greater conformity by asking whether the path towards internationalisation is a strategic pattern that is equally pursued by individual companies in the industry.

The motivation for this question and thus the paper's intent to add to the rather sparse literature on the internationalisation of individual shipping companies are outlined in the next section. It also refines the research question and introduces the study's specific approach.

\section{Motivation for the paper's specific research question}

$\mathrm{Xu}$ et al. (2015) analyse the global shipping network at an industry level and conclude that the rapid economic growth of emerging countries, such as China and India, over the past two decades has stimulated carriers to adjust their operations worldwide for better coverage of their service networks and higher revenues. Consequently, the structure of the global shipping network has dynamically evolved, currently showing Asia, Europe and North America as the three largest trade zones. Asia is not only one of the main sources of the products that are consumed in Europe and the Americas, but Asian countries and companies are also among the major players in the global maritime sector. Related liner services constitute the East-West belt of global shipping activities, while ports in Africa, for example, attract much fewer container vessels (Xu et al., 2015).

The analysis thus shows a comprehensive global network of container routes with regional differences, which are primarily based on volumes and capacity allocation. However, the analyses in this study and that of related papers (see Xu et al., 2015 for an overview) are conducted for the shipping network as a whole. It is not separated into network considerations and differences of individual companies and does not necessarily confirm the above proposed development of the individual companies from being regionally oriented to becoming global actors.

Overall, containerisation is naturally suited to globalisation, but at the single-company level, shipping operations still appear fragmented, while their environment is volatile (Lee and Song, 2017). Accordingly, individual patterns of internationalisation may be rather different from those of the industry as a whole. As Lee and Song (2017) propose, the complexity of container shipping arises not only from border-crossing issues and multimodal transport over long distances but also from the involved parties that pursue their own strategies and objectives.

Current research on the internationalisation of individual companies in liner shipping is sparse and points towards traditional financial considerations, yet also mentions the 
growing importance of strategic and synergistic expansion motives in the industry (Brooks and Ritchie, 2006; Cariou, 2007).

In fact, recent work (Gadhia et al., 2011; Ducruet and Notteboom, 2012) on the network structures in the industry supports the idea that container-shipping companies show different patterns of internationalisation and operate based on various related strategies. Consequently, Gadhia et al. (2011, p. 1438) and Ducruet and Notteboom (2012, p. 399) only mention a few companies that appear to be "truly global" by calling ports in almost all world regions, while others concentrate their business on range-to-range services between ports in the major trade zones.

These earlier approaches primarily focus on the physical port and network structures and therefore only the country presence in terms of port calls as an indicator of internationalisation. Following McCalla et al.'s (2004, p. 473) argument that "[...] strategies at sea appear to break down when the goods reach the port", the term "truly global" may also be perceived in a broader scope than just the sea-oriented physical operations.

On the sea side, carriers operate in a rather standardised manner, and the current popular alliances are also means to extend global coverage (Panayides and Wiedmer, 2011). However, while carriers may compete or cooperate in terms of operations (ship type or size, number of ships, port selection and sequence and ship sailing schedule), the cooperation mechanisms typically do not involve pricing, revenue pooling, profit/loss sharing and joint management and executive functions (Panayides and Wiedmer, 2011). Still, each shipping company has its individual network of agents, forwarders and agreements with shippers to handle goods on land (McCalla et al., 2004).

Thus, in container shipping, convergence and standardisation may take place at sea, while land activities are dominated by specialisation (McCalla et al., 2004). Consequently, contrasting patterns of internationalisation on the sea side and on the land side may provide further interesting insights into the industry's patterns and strategies.

A more complete examination of the cross-border configuration of containershipping companies is thus needed before conclusions can be drawn about the internationalisation pattern of the industry and its main actors. Following the basic premise of internationalisation (Dunning and Lundan, 2008), other measures, such as the number of countries and the degree of internationalisation of owners and the management, should also be assessed.

Based on all the presented considerations, this paper aims to further examine internationalisation in liner shipping through an investigation of the front-end activities and the structures of shipping companies, as expressed by the presence of sales offices and the overall extent of the market presence, for example. The central research question is refined as follows:

$R Q 1$. What is the internationalisation pattern of container-shipping companies as indicated by the cross-border sales offices and the agents of the market players in the industry?

This paper seeks confirmation of its underlying assumption that not all carriers demonstrate global presence, through patterns pointing at different strategies towards internationalisation compared to previous attempts. In this context, it also investigates whether market share and total capacity are necessarily good indicators of a company's worldwide presence.
Shipping lines: examining sales network 
MABR

2,3

282

The research question was investigated from the perspectives of the 20 largest single carriers in the sector, based on the data from Alphaliner (2012) (Table I) and the numbers of their sales offices and sales agents in different countries and world regions. Drawing conclusions from the answer to the question provides a better picture of the overall pattern of internationalisation and the cross-border strategies employed in the transportation sector.

While extant research has already tried tackling this question in terms of logistics service providers (Lemoine and Dagnæs, 2003; Mentzer et al., 2004; Murphy and Daley, 1996), the question remains unaddressed in terms of the carriers that operate the services. Existing research therefore fails to acknowledge the subtle but important cross-border orientations that may exist in the way that carriers operate (Gadhia et al., 2011)[1]. This knowledge will aid in understanding the degree to which the carriers' cross-border strategies are aligned with those of the logistic service providers and help in understanding shipper-carrier relationships for international logistics (Heaver, 2002).

The remainder of this paper is organised as follows. The next section presents a discussion on the different approaches to internationalisation. It also reflects on the existing work about the degree of internationalisation in container shipping. A short introduction of the methodological approach is followed by the basic results of the analysis on the 20 leading container-carrying companies, with respect to both their international networks of sales offices and the ratio of their own offices to the offices operated by external agents. The composite measures are built on this basis. Finally, the internationalisation pattern of the single companies is briefly interpreted in the final section.

\section{Internationalisation of companies}

The internationalisation of companies is basically understood as a process of increasing involvement in cross-border operations. It is explained by the degree of the commitment to a

Table I.

Top 20 container carriers

\begin{tabular}{clcc}
\hline Rank & Carrier & Capacity in TEU & Market share in (\%) \\
\hline 1 & A.P. Moller - Maersk & $2,544,760$ & 15.8 \\
2 & Mediterranean Shipping Company (MSC) & $2,222,497$ & 13.8 \\
3 & CMA CGM Group & $1,322,443$ & 8.2 \\
4 & China Ocean Shipping (Group) Company (COSCO) & 664,693 & 4.1 \\
5 & Hapag-Lloyd & 632,556 & 3.9 \\
6 & Evergreen Line & 612,007 & 3.8 \\
7 & American President Lines (APL) & 603,514 & 3.7 \\
8 & China Shipping Container Lines (CSCL) & 550,492 & 3.4 \\
9 & Hanjin Shipping & 483,541 & 3.0 \\
10 & Mitsui O.S.K. Lines (MOL) & 460,702 & 2.9 \\
11 & Nippon Yusen Kaisha (NYK) Line & 409,457 & 2.5 \\
12 & Orient Overseas Container Lines (OOCL) & 403,510 & 2.5 \\
13 & Hamburg Süd Group & 401,607 & 2.5 \\
14 & K Line (Kawasaki Kisen K.K.) & 346,042 & 2.1 \\
15 & Yang Ming Marine Transport Corp. & 334,480 & 2.1 \\
16 & Hyundai Merchant Marine (HMM) Co. & 329,231 & 2.0 \\
17 & ZIM Integrated Shipping Services Ltd & 322,943 & 2.0 \\
18 & Compania Sud Americana de Vapores (CSAV) & 310,237 & 1.9 \\
19 & Pacific International Lines (PIL) & 268,984 & 1.7 \\
20 & United Arab Shipping Company (UASC) & 240,190 & 1.5 \\
& & & \\
Notes: CMA = compagnie générale maritime; CGM = compagnie générale maritime & \\
Source: Alphaliner (2012) & & \\
\hline
\end{tabular}


specific market, the selection of particular markets or both commitment and selection (Hotho, 2009; Welch and Luostarinen, 1988). The related discussion about the degree of internationalisation in contrast to a potential regionalisation of companies is not new at all.

For multinational enterprises, Rugman $(2000,2005)$ has asked whether some global companies are in fact regional in nature. There are also observations of such companies that opt for more regional marketing strategies and thus balance between globalisation and localisation (Khan, 2010). Regionalisation in this context refers to accepting the significant differences between countries and regions.

Internationalisation and globalisation then do not only mean being present in different countries but also reflecting and handling such differences (Dörrenbächer, 2000). In other words, this point also adds to the more general question of whether regional strategies only belong to a temporary stage before a domestic firm becomes truly global or whether global firms' approaches break down into regional strategies (Khan, 2010). A better understanding of these dynamics between regionalisation and globalisation is vital for the analysis and the construction of related strategic approaches in multinational enterprises. An essential contribution to such comprehension is observed in the operationalisation and the measurement of the degree of internationalisation.

Approaches for empirically capturing the degree of the internationalisation of a corporation's business activities are plentiful in the literature, particularly the academic international business studies (Gerpott and Jakopin, 2005). For instance, Dunning and Lundan (2008) suggest measuring the internationalisation of companies based on seven criteria, as follows:

(1) the number and the size of foreign companies and joint ventures controlled by a company;

(2) the number of countries where the company is active;

(3) the global sales volume and the number of employees worldwide;

(4) the degree of internationalisation of the company's owners or management;

(5) the degree of internationalised capital-intensive business areas such as research and development;

(6) systemic advantages within the company based on foreign activities of the whole company; and

(7) the number of foreign activities that affect the company's strategic decisions.

Based on a broad review, Gerpott and Jakopin (2005) conclude on an agreement in the literature that no single indicator of business internationalisation outperforms the other measures in terms of validity. Consequently, for their work on the internationalisation of telecommunication markets, they do not propose a single operationalisation but a total of different measures that reflect and combine different dimensions (Ietto-Gillies, 1998; Sullivan, 1994). The dimensions may be grouped into the following three categories (Dörrenbächer, 2000, Gerpott and Jakopin, 2005, Lin, 2012):

(1) there are structural variables relating to foreign activities (e.g. the number of countries where the company is active, the proportion of foreign affiliates, foreign assets), on one hand, and relating to governance structures (e.g. the number of stock markets, shares owned by foreign investors and the number of non-nationals in the boards), on the other hand;

(2) outcome variables reflect foreign sales and operating income abroad and thus the market-related results of international business; and
Shipping lines: examining sales network

283 
MABR

2,3

(3) attitudinal variables denote soft and hard indicators, such as the geocentric management style or the international experience (measured in years) of top managers, which capture cross-country facets of corporate or business unit behaviours of internationalised firms.

While individual internationalisation indicators basically measure the selection in terms of a dichotomised approach of home versus foreign (Dörrenbächer, 2000), more or less in absolute numbers, there are also approaches that put the degree of internationalisation more in the context of regional diversification. Such approaches place the proportions and the ratios of internationalisation in the forefront and thus more of the differences in the commitment to certain markets. Examples are provided by Perriard (1995), who measures regional concentration based on indexes that relate to Gini coefficients and the Herfindahl index, which refers more to geographical and cultural distances. Another instance is the work of Ietto-Gillies (1998), who defines a network-extension index.

When the measurement refers less to the description of a defined level of internationalisation and more to the process of internationalisation, then the internationalisation process theory is of special relevance. This theory places the development pattern, the when, where and how (Hotho, 2009), in the forefront. According to internationalisation process theorists (Johanson and Wiedersheim-Paul, 1975), the commitment of resources to a foreign market is restricted by the local market knowledge. With increasing experience, by gaining more local market knowledge, the involvement is supposed to increase with regard to the mode of operation and the commitment of resources (Johanson and Vahlne, 1990, 1977).

The theory combines structural measures, such as market size and market potential, with attitudinal measures, such as differences in language, culture and political systems for a company's foreign market selection. Countries where companies experience less uncertainty and disturbance in the flow of communication have higher psychological closeness to the home market (Johanson and Vahlne, 1977; Johanson and Wiedersheim-Paul, 1975) and are thus more likely to be entered prior to the more distant and less similar markets (Johanson and Vahlne, 1990). Consequently, this makes internationalisation a development process of gradual "learning through experience", which is labelled as an "establishment chain" (Johanson and Wiedersheim-Paul, 1975, p. 307).

The related stage models of internationalisation thus pay attention to the developed number of offshore markets and the depth of a firm's direct exposure to these markets (Chetty and Campbell Hunt, 2003; Gadhia et al., 2011; Kotler and Keller, 2012). One of the most frequently used models, which reflects the basic logic of the international process theory, is the Uppsala or the Nordic model. It highlights four stages in an international development process, as follows: no regular export activities, export via independent agents, creation of an offshore sales subsidiary and finally, overseas production facilities. The international process theory is therefore still the dominant one for explaining the processes by which firms internationalise and as such has also been used to understand international logistic operations (Murphy et al., 1988). The related basic model remains virtually unchanged, and to some extent, this is also a testimony to the model's relative robustness and to the appeal of understanding internationalisation as a process (Hotho, 2009).

\section{Internationalisation of container-shipping companies}

While the preceding section has dealt with the internationalisation of companies in general, this section briefly focuses on the related work in the narrower field of container shipping. Considering that the container carriers are per se regarded as international 
(Gadhia et al., 2011) companies, unsurprisingly, not much work so far has tackled the question of the degree of internationalisation of these firms.

Slack and Frémont (2005, p. 117) investigate the transformation of port terminal operations "from the local to the global". In their work, which basically refers to the structural indicator of governance and ownership, they conclude that the terminal industry is transformed by the penetration of transnational operators, such as Hutchinson Port Holdings and Port of Singapore Authority International. However, they also draw attention to the fact that the transformation process has been rather uneven and that important regional differences exist. Their work is especially interesting, given that the transformation towards global management is additionally driven by carriers that vertically integrate into terminal operations worldwide. Such involvement may fundamentally be driven by a search for levers for providing economies of scale and scope, as well as the required control of terminals and hinterland operations as a key to worldwide door-to-door services. However, it might also be an interesting indicator of the carriers' commitment in certain areas of the world.

Ducruet and Notteboom (2012) draw conclusions about the development of the shipping network structure, particularly regarding the relative position of ports in such networks, by analysing the global container-shipping networks in 1996 and 2006. Their major object of analysis thus refers to the hierarchical structure of the port network as a whole, emerging regional patterns and the dynamics influencing the network. The basis for their analysis is the daily vessel movement observed over 365 days of the two respective years. By analysing the "topological properties of the global maritime network" (Ducruet and Notteboom, 2012, p. 404) and, for instance, the connectivity and the centrality of ports in the network, their work aims to examine the patterns and the indicators of hierarchy and to concentrate on the physical network of ports. It is thus somewhat similar in its basic approach to that of Fremont (2007). However, while Fremont's (2007) work is based on the analysis of the network of a single company (i.e. Maersk), Ducruet and Notteboom's (2012) study is broader, analysing the patterns of the whole container industry.

They conclude that although flows between hubs and gateways may slightly shift among nodes, the topological properties remain rather stable as a whole. There might be some bottom-up adjustments due to congestion issues at the port-urban interfaces. Topdown adjustments occur because of the competition among shipping lines, as a number of shipping lines show approaches towards differentiation, seeking competitive advantages by fully or partially controlling (semi-)dedicated terminal facilities. However, this happens in parallel to the network's increasing size and complexity (Ducruet and Notteboom, 2012). The authors' analysis thus confirms the strong influence of geography and distance on the distribution of maritime traffic. This implies that Ducruet and Notteboom (2012) identify a rather stable context of physical flows, expressed in port architecture and flow patterns between ports. However, the positioning of the single players and the development patterns of the single actors in this total context may vary.

Gadhia et al. (2011) reflect on the individual port networks of the single players and particularly apply an approach that in its core is based on a combination of Johanson and Vahlne's (1977) Uppsala model and the stage model of internationalisation presented by Chetty and Campbell Hunt (2003). Gadhia et al. (2011) follow a proposal for zone differentiation (Degerlund, 2006) in their analysis of the port calls of the 19 largest containershipping companies and group the global container market into regions and subregions and by country.

Adopted from Gadhia et al. (2011), Figure 1 then allows for a comparison of the ports with their neighbouring container ports, as well as the observation of the regional structure and characteristics.
Shipping lines: examining sales network 
MABR

2,3

286

Figure 1.

Comparison of corporate port networks

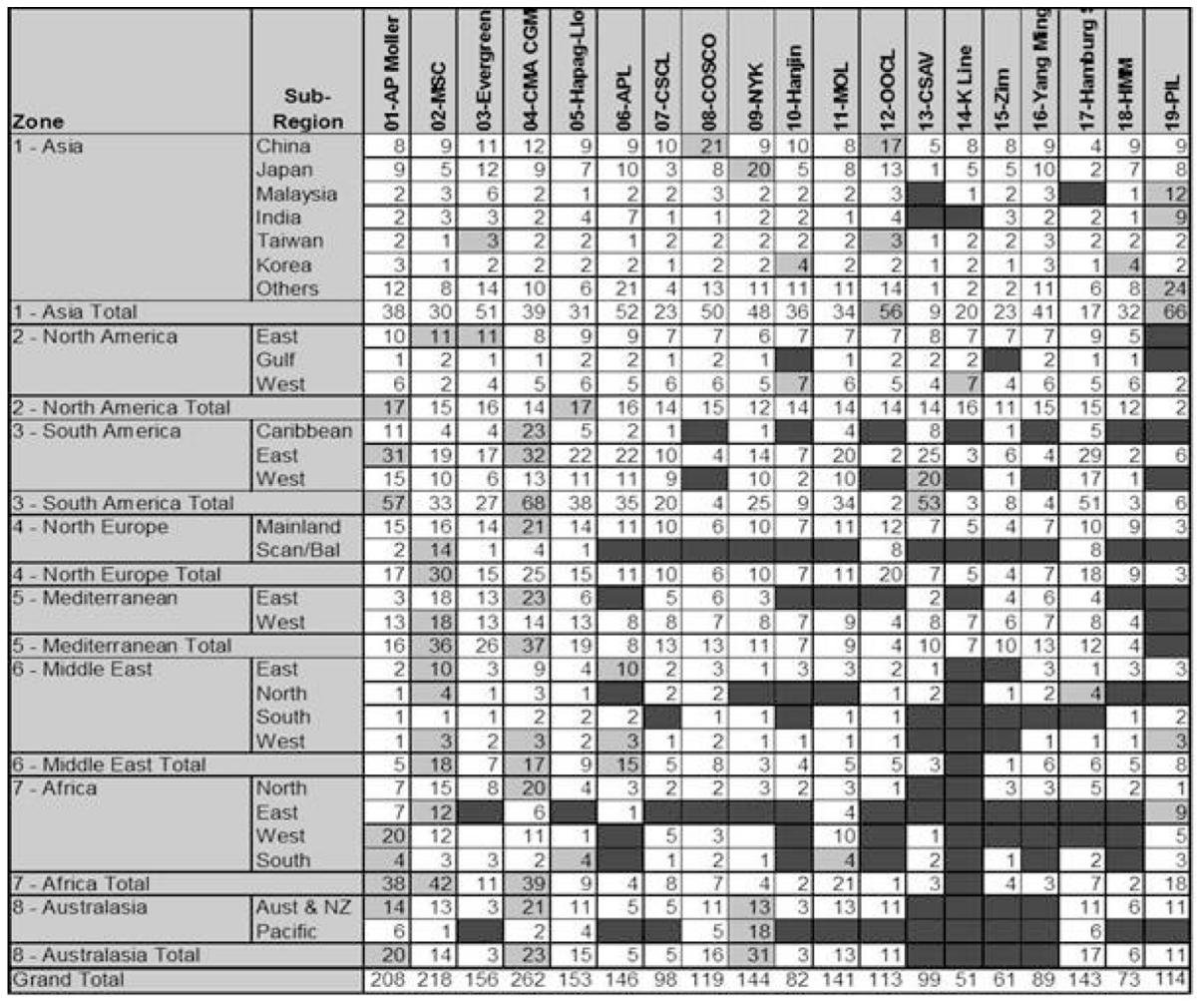

Source: Adapted from Gadhia et al. (2011)

The grey shading in Figure 1 indicates where a regional network is dominated by a company, where it services more container seaports than other companies do. The black shading signifies the absence of a company in a region. The numbers indicate how many container seaports in a region are serviced by any given company. Furthermore, Gadhia et al.'s (2011) results show that only three of the 19 surveyed companies service the major and the minor ports distributed across the globe and can thus be considered truly global. The port networks of the other companies in the survey share common characteristics while having individualised features. In fact, some companies apparently act rather regional, while others exhibit truly worldwide behaviours. Based on these patterns, Gadhia et al. (2011) identify four levels of a container-shipping company's port network.

Consequently, the first investigation of the industry has shown that container-shipping companies may operate rather differently, with various motives for internationalisation. Particularly, the work of Gadhia et al. (2011) reflects on different patterns of the individual companies, measured in the physical port network. Though this work appears relevant, useful and interesting, it also has some potential deficits.

For instance, in addition to the number of port calls in a region, Gadhia et al. (2011) also develop the average ship size as an indicator to differentiate the company's commitment towards certain zones. As most companies also charter different shares from and to other carriers on the basis of slot-sharing agreements, ship size and total capacity (measured in 
twenty-foot equivalent unit [TEU]) are somehow difficult to measure for the single companies.

Similar problems may also arise in the measurement of port calls, as this does not necessarily take into account the practice of alliance agreements. Single companies may augment their network by relying on alliances with other partners (Panayides and Wiedmer, 2011; Ryoo and Thanopoulou, 1999). If a researcher follows the work of Ducruet and Notteboom (2012), then the context of the routings and the flows between ports is rather stable. The development of single actors is thus also a matter of replacement and mergers within the competition. These may take time; thus, patterns are perhaps not always recognisable in the short term.

To this extent, the internationalisation differences of container-shipping companies are only partly explained by existing research, which has examined the physical network properties, such as port calls and the overall port network structure of the largest shipping providers. Besides this back end of the service architecture, there are also aspects on the front-end side towards the customer that reflect the internationalisation patterns of container-shipping companies.

\section{Measuring internationalisation based on front-end activities}

This paper seeks to make a contribution by adding an additional facet to the existing work and focuses on the worldwide network of sales offices as a complementing indicator of internationalisation. The numbers of worldwide sales offices of the top 20 container carriers are investigated based on the companies' publications and information from their websites and corporate databases. Next, composite measures of the total number of sales offices, combined with additional indicators, are created. The presence of each company's sales offices in the eight international zones (Figure 1) is then measured as a simple first indicator. This measure follows the ideas from the previous section and deals with the issue of homogeneity versus heterogeneity of the international presence. Further on, a distinction is made based on whether the companies own the sales offices or the carriers employ the support of external agents. This measure reflects the ideas of a networkspread index and refers to Chetty and Campbell Hunt's (2003) stage model.

This study further analyses the various relations among the variables based on Spearman's rho, applied due to the low number of cases in the non-parametric KruskalWallis test.

\section{Findings}

Analysing the total network of sales offices around the world identifies around 5,000 offices. This means an average of about 258 offices for the average shipping company. Table II provides an overview on the selected carriers and their sales offices worldwide.

When setting the market share in relation to the number of each company's own offices, this study identifies a significant positive correlation between these two variables. Thereby, the study is able to determine that the average number of sales offices of companies with a high market share is significantly higher than that of competitors with a low market share (based on the non-parametric Kruskal-Wallis test). However, these general results do not hold when analysing the data in a more qualitative manner (as Table II indicates). Overall, the comparison of the number of sales offices with the market share does not show any definite correlation between them, although it is possible to identify some initial interesting patterns.
Shipping lines: examining sales network 


\section{MABR}

2,3

\section{8}

Table II.

Carriers and their sales offices worldwide

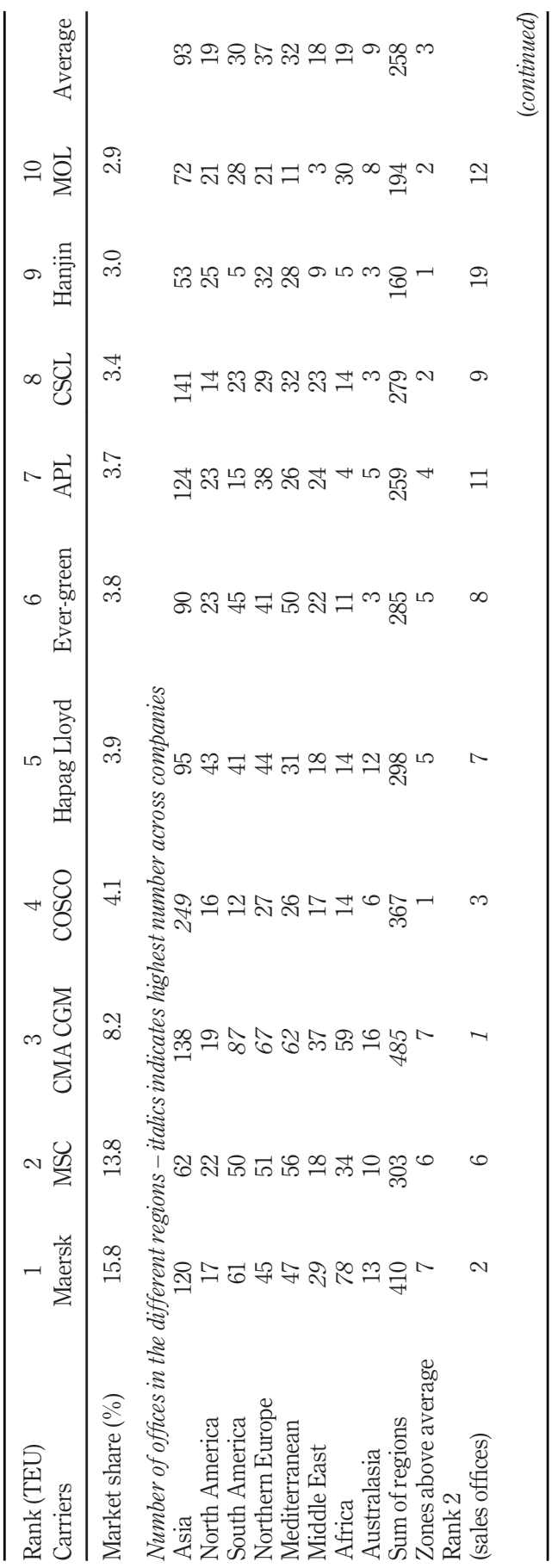




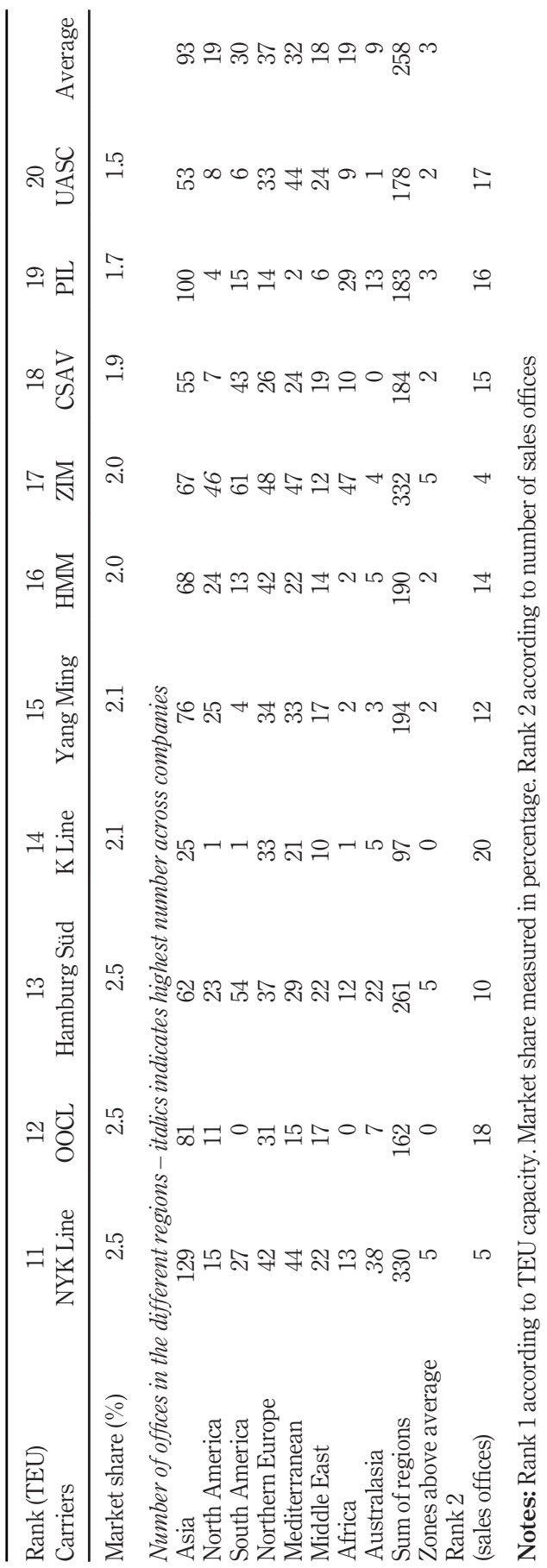

Shipping lines: examining sales network

289 
MABR

2,3

290

Notably, although Maersk Line holds the largest capacity, it does not own the highest number of sales offices. Instead, with only about half the capacity of Maersk Line, the French CMA CGM Group operates about 20 per cent more sales offices worldwide.

Conversely, the Mediterranean Shipping Company (MSC) has over 100 sales offices worldwide, less than the Danish market leader Maersk at approximately 87 per cent capacity. Nippon Yusen Kaisha (NYK) Line has 330 sales offices worldwide, although it has only 2.5 per cent of the global capacity. Orient Overseas Container Lines (OOCL), which also serves 2.5 per cent of the global capacity, is not even represented in the two continents of Africa and South America. In contrast to its closest competitors of equal size, the Japanese shipping company K Line has just 97 sales offices worldwide. Yang Ming possesses an almost similar capacity, but over 194 sales offices. The patterns then become yet more distinct when focusing on the single regional zones.

\section{Zone 1: Asia}

When observing the individual regions, it is striking that the MSC - the world's second largest container-shipping company (in TEU) - only has 62 sales offices in Asia. This number is significantly less than the average of 93 sales offices in this important area of the world. In contrast, the Chinese shipping company China Ocean Shipping (Group) Company (COSCO) operates 249 sales offices, of which 191 are in China. In all other regions, COSCO is below average. The Japanese K Line has only 25 sales offices in the region, which is still a quarter of its total sales outlets. For the 20 shipping companies studied here, 36 per cent or 1,860 of the 5,151 sales offices worldwide are located in Asia. Asia thus shows by far the most sales offices among the different regions.

\section{Zone 2: North America}

North America has on average 19 sales offices per shipping company, although the area has only three countries (the USA, Canada and Mexico). A prominent characteristic of the region is that both CMA CGM and Hapag Lloyd have offices above the average number here, particularly in the USA. K Line operates the least number of offices (just one) in North America, one of the economically more important parts of the world.

\section{Zone 3: South America}

Overall, the 20 container-shipping companies have 591 sales offices across the South American continent. In this region, OOCL operates no offices at all, while K Line has just one location. Yang Ming has only four sales offices in the continent, comprising only one-fiftieth of all outlets of this company. Other operators, especially CMA CGM and Hamburg Süd, have very large numbers of sales offices in South America. The Chilean shipping company Compania Sud Americana de Vapores (CSAV) operates 43 sales offices in the continent, of which only one is located in its home country, but 10 units are in Brazil.

\section{Zone 4: Northern Europe}

The Northern European region shows a rather homogeneous distribution. With an average of more than 30 sales offices per company, Northern Europe is the next most populated after Asia in terms of its sales offices. All the investigated container-shipping companies have offices in Europe. Pacific International Lines (PIL) has the smallest number (14) of offices; however, it only has 1.7 per cent of the global shipping capacity. With its origin and head office in France, the CMA CGM Group maintains the highest number of sales offices. The MSC, Maersk Line, Hapag Lloyd and Hamburg Süd all have their headquarters in this 
region as well. This means that 44.2 per cent of the global container-shipping capacity is located in Northern Europe.

\section{Zone 5: Mediterranean}

All of the 20 surveyed carriers are represented by sales offices in the Mediterranean region. On average, the container lines maintain 33 outlets there. However, it is striking that PIL has only one sales office each in Turkey and Italy, while the United Arab Shipping Company (UASC), which is the smallest shipping line investigated, operates 44 sales outlets in the region.

\section{Zone 6: The Middle East}

The Middle East shows no specific irregularities. All shipping companies operate sales offices in the region. In Afghanistan, only the CMA CGM Group holds a sales office. Afghanistan is just provided as an example to show that some countries in this region only have small numbers of sales offices or none at all.

\section{Zone 7: Africa}

Excluding the Mediterranean nations, Africa comprises over 50 countries and a great deal more of different people and languages. However, the 20 largest container-shipping lines have an average of just over 19 sales offices. The Israeli ZIM lines, Maersk Line, MSC, Mitsui O.S.K. Lines (MOL) and PIL must be considered the five largest container-shipping companies in the region. Almost two-thirds of the African sales offices operate in the service of these companies. Moreover, the market leader Maersk Line operates by far the highest number of sales offices in the continent. With around 160 outlets worldwide, OOCL does not even have a single sales office in Africa.

\section{Zone 8: Australasia (Australia, New Zealand and Oceania)}

In the region comprising Australia, New Zealand and Oceania, the average number of sales offices is only nine, and most (five) are on average located in Australia. While some shipping companies, such as Hyundai Merchant Marine (HMM), do not even maintain a single sales office in the region, NYK has 38 offices. However, as the next section shows, 78 per cent of these 38 offices are operated by agents.

\section{Ownership ratio: sales agents versus own offices}

So far, the numbers of sales offices have been investigated, and a measure on the homogeneity with regard to the geographical coverage across the single regions has also been provided. It may also be interesting to research on the degree of ownership of the sales offices. To obtain the figures of the ownership structure, the numbers of sales agents that operate with company names that differ from those of the carriers are considered. For other agents that act as distinct companies but with names related to their respective carriers, legal or taxation reasons for this independence are assumed. On this basis, Table III provides the ratio of sales offices operated by agents to the container-shipping companies' own sales offices per region.

For all 20 companies, the ratio adds up to 46 per cent of the sales offices that are operated as agencies. Involving agents has the advantage of using their local knowledge for a faster and easier entry into markets without taking the related risk and making the investment. Following Chetty and Campbell-Hunt's (2003) study, the tendency to shift from employing an agent to establishing a company's own office is thus a potential indicator of a progressing internationalisation. At the same time, there is also a possible linkage to the resource

\section{Shipping lines: examining sales network}

291 
MABR

2,3

292

Table III.

Ratio of agents to a company's own sales offices (numbers show percentages)

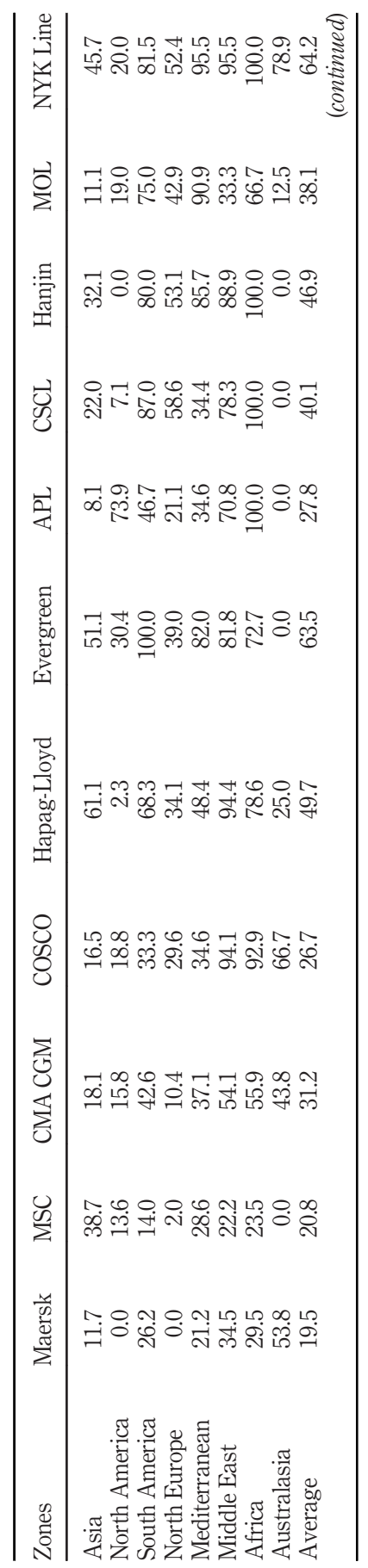



sales network 
MABR

2,3

\section{4}

potential of the respective companies. In contrast to the number of offices, the degree of ownership shows a relationship to the rankings based on market share, except for some outliers, such as American President Lines (APL), MOL and OOCL. The market leaders Maersk and MSC just have a fifth of their offices represented by agencies.

These results are confirmed by a general correlation analysis, which shows a significantly negative correlation between market share and agency offices.

\section{Discussion of results}

Putting the pieces together, it is now possible to apply a kind of composite measure to describe the degree of internationalisation of container-shipping companies in terms of sales offices.

Figure 2 illustrates the positioning of the single companies according to sales offices ( $\mathrm{x}$ axis), the homogeneity of the geographical coverage (y-axis) and the ownership of the offices (bubble size). From this perspective, four groups could be identified. The first group consists of only two companies, Maersk and CMA CGM, reflecting a truly global pattern with respect to sales offices. It is then noteworthy that the largest company does not have the largest number of sales offices and that a company with almost half the market share of the largest player has 20 per cent more sales offices worldwide.

The analysis of the regional presence of the companies (according to their representation in the seven zones) shows that 9 companies are present in more than four zones, and 11 companies are represented in less than four zones. It is no surprise to find a positive correlation between the regional presence and the size of the market share based on TEU capacity. Based on a Kruskal-Wallis test, it is also not startling to observe a statistically significant, higher market share for the group of companies represented in more than four zones than for the other group. Nevertheless, the individual qualitative assessment of each company allows gaining more specific insights into this relationship.

On the opposite end of the spectrum is the group of nine companies (K Line, OOCL, Hanjin, CSAV, MOL, HMM, UASC, Yang Ming and PIL), whose number of offices and coverage of the regions are by far lower. The findings for this group are consistent with the results of Gadhia et al. (2011), who sort these firms (based on the network of port calls) into the internationalisation stage of "home/legacy". In the present analysis, a high ratio of the companies' own offices to the agencies of some of the firms (such as OOCL and HMM) also indicates a stronger commitment to these home markets.

Figure 2.

Degree of internationalisation of shipping companies

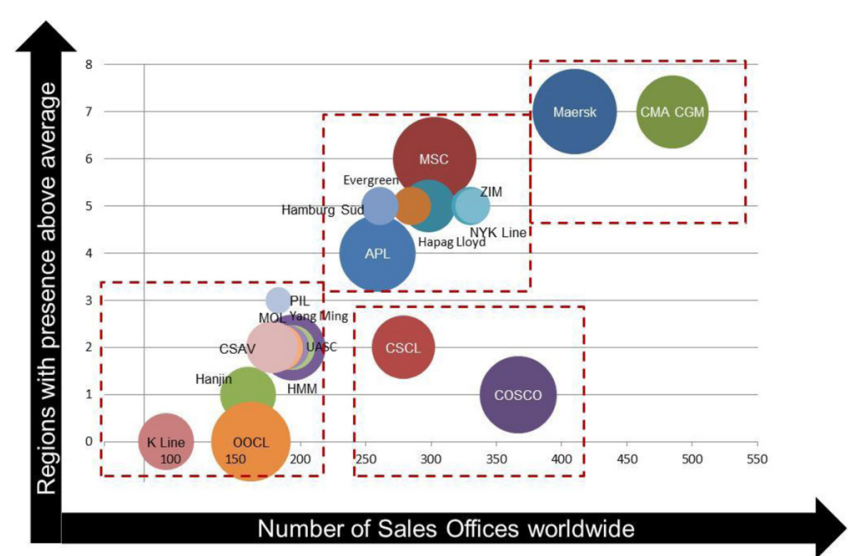


For those companies, particularly OOCL and HMM, Gadhia et al. (2011) find a higher average ship size. This leads them to the similar conclusion that these companies are not global but operate with a regional focus.

A more specific group is that clustering China Shipping Container Lines (CSCL) and COSCO, showing a pattern of low coverage across regions, similar to that of the companies in the previous group. However, the two companies have rather high numbers of offices worldwide. For example, with its 367 offices, COSCO ranks number three when measured by the number of sales offices, above companies such as the MSC. The fact that about three out of four offices are operated by the company and that 68 per cent are located in Asia also indicates a clear local commitment. The same pattern holds for CSCL.

Finally, somewhere in between lies the group of seven companies, comprising APL, Hamburg Süd, Hapag Lloyd, NYK, ZIM, Evergreen and the MSC, which apparently show a tendency towards being global, while falling behind the two market leaders. A similar group pattern has been identified by Gadhia et al. (2011, p. 1440), who call the group "The bunch of others: Going what direction?" However, the MSC's positioning is somewhat different; in terms of its port calls, it is more globally positioned than Maersk but not in terms of its sales offices. This might be due to the MSC's peculiar company history compared with most of the other rather traditional companies.

\section{Conclusion and outlook}

The present study confirms some of the results of previous studies on the topic, particularly that of Gadhia et al. (2011), that only a few companies in fact demonstrate global presence in an industry that is assumed to be highly internationalised. Nonetheless, this present work also adds a new facet to the question about the internationalisation of container-shipping companies. Even though we were able to identify a significant correlation between size (in terms of market share) and internationalisation (in terms of number of sales offices), our qualitative data analysis revealed some more interesting insights showing that the relationship between size and internationalisation may probably not be linear. As, for example, the largest company of our analysis did not possess the highest number of sales offices and therefore is not so international from this perspective.

This means that it needs to be reconsidered whether such correlation is indeed important to emphasise when thinking about internationalisation in the container-shipping industry. At the same time, it is interesting to note that the Asian region contributes to most of the sales offices in the world. This could definitely imply that market-specific internationalisation is happening, sales offices do matter and companies are following more specific modes of entry and expansion into some markets.

Next, it would be noteworthy to find two (or a few) markets where each of the biggest players is equally active and then to compare the ratio of sales offices to agents.

The study also adds different insights to other results, for example, the positioning of individual companies such as the MSC and COSCO. However, it should be noted that this present investigation has certain limitations due to its general approach. Some of the companies, such as NYK and COSCO, are more engaged in other shipping market segments (e.g. tankers, bulkers), more general logistic businesses, short sea operations and so on, than their competitors.

The differences in the numbers of sales offices of single companies may thus also result from overlaps and synergies with such segments that are not directly linked to the container market. The single companies also show different historical development patterns that might have had effects on the structure of their sales offices. For instance, Maersk has grown significantly by its acquisitions of Sea-Land and later P\&O Nedlloyd; in contrast, the

\section{Shipping lines: examining sales network}


MABR

2,3

296

MSC has become organic. This may have caused different representations of offices worldwide. While this present research thus adds another general indicator of the internationalisation pattern in the industry, it also indicates further potentials for research, particularly on the single companies and their individual patterns of internationalisation.

Related questions may refer to path dependencies, tactical considerations or contingency factors that affect such location decisions. More detailed research could also address different marketing requirements with respect to various world regions or the focus on different marketing channels.

Beyond the pure patterns of internationalisation, it would also be quite interesting to link the specific patterns to the performance of the individual companies and to investigate the decisions that basically lead to the individual companies' internationalisation in more detail.

Finally, the authors are fully aware that this paper's contribution, with all its limitations, is primarily of a theoretical-conceptual nature. Nonetheless, adding a front-end view to the typical analysis of the physical, sea-oriented network may also help in interpreting the strategies and the context of carriers, which should be of practical interest.

Currently, the industry is shaken by the recent bankruptcy of Hanjin Shipping. According to Gadhia et al. (2011), Hanjin operated with a legacy model in the form of rather limited internationalisation but with a concentration on core strings, which were served by relatively large vessels. This present paper's front-end perspective indicates Hanjin's tendency towards a regional sales network, which is also one of the smallest (Figure 1). Combined with the fierce competition in the serviced market segment, this may be perceived as a weak basis for success. However, the authors are aware that the study's results may just indicate such a potential weakness; for a substantial conclusion, further, more detailed research is needed.

The other major development these days is the emergence of major carrier alliances (Knowler, 2017). In terms of the sales networks, the three largest alliances consist of heterogeneous sets of actors. Maersk and the MSC are partners under the 2M label with Hamburg Süd and HMM. CMA CGM works together in the "Ocean Alliance" with COSCO, Evergreen and OOCL. "The Alliance" consists of Hapag-Lloyd, Yang Ming, UASC, NYK, MOL and K Line, characterised by their sales networks as home or core market players. It could be interesting to investigate whether carriers with different internationalisation patterns would consistently show differences in behaviour and performance as well.

The authors recognise the main purpose of the current alliances in terms of improvements in cost and transit time (Knowler, 2017). Primarily, they are organised as slot-sharing agreements and concentrate on the main strings as identified in the study of Xu et al. (2015). It could be noteworthy to examine how far the alliances would also increase the geographical coverage of the single actors and how far this would affect the non-physical activities. To achieve the necessary depth of information, case studies might constitute an appropriate method.

\section{Note}

1. As Gadhia et al. (2011) point out, this is probably due to the inherent cross-border nature of the business and the related assumption of globalised service providers.

\section{References}

Alphaliner (2012), “Alphaliner - top 100”, available at: www.alphaliner.com/top100/ (accessed 20 March 2012).

Brooks, M. and Ritchie, P. (2006), "Mergers and acquisitions in the maritime transport industry 19962000", Transportation Journal, Vol. 45 No. 2, pp. 7-22. 
Cariou, P. (2007), "Liner shipping strategies: an overview", International Journal of Ocean Systems Management, Vol. 1, pp. 1-6.

Chetty, S. and Campbell Hunt, C. (2003), "Paths to internationalisation among small to medium sized firms: a global versus regional approach”, European Journal of Marketing, Vol. 37 Nos 5/6, pp. $796-820$.

Degerlund, J. (2006), Containerisation International Yearbook, Informa Group, London.

Donovan, A. and Bonney, J. (2006), The Box that Changed the World: Fifty Years of Container Shipping - An Illustrated History, Commonwealth Business Media, East Windsor, NY.

Dörrenbächer, C. (2000), "Measuring corporate internationalisation”, Intereconomics, Vol. 35 No. 3 , pp. 119-126.

Ducruet, C. and Notteboom, T. (2012), "The worldwide maritime network of container shipping: spatial structure and regional dynamics”, Global Networks, Vol. 12 No. 3, pp. 395-423.

Dunning, J.H. and Lundan, S.M. (2008), Multinational Enterprises and the Global Economy, 2nd ed., Edward Elgar, Cheltenham.

Fremont, A. (2007), "Global maritime networks: the case of maersk", Journal of Transport Geography, Vol. 15 No. 6, pp. 431-442.[InsertedFromOnline]

Gadhia, H.K., Kotzab, H. and Prockl, G. (2011), "Levels of internationalization in the container shipping industry: an assessment of the port networks of the large container shipping companies", Journal of Transport Geography, Vol. 19 No. 6, pp. 1431-1442.

Gerpott, T.J. and Jakopin, N.M. (2005), "The degree of internationalization and the financial performance of european mobile network operators”, Telecommunication Policy, Vol. 29 No. 8, pp. 635-661.

Heaver, T.D. (2002), "The evolving roles of shipping lines in international logistics", International Journal of Maritime Economics, Vol. 4 No. 3, pp. 210-230.

Hotho, J. (2009), Internationalization Decisions: The Effects of Country Differences and Familiarity Perceptions, PPI Publisher, Enschede.

Ietto-Gillies, G. (1998), "Different conceptual frameworks for the assessment of the degree of internationalization: an empirical analysis of various indices for the top 100 transnational corporations", Transnational Corporations, Vol. 7, pp. 17-40.

International Chamber of Shipping (2017), "Shipping facts", available at: www.ics-shipping.org/ shipping-facts/shipping-facts (accessed 30 April 2017).

Johanson, J. and Vahlne, J. (1990), “The mechanism of internationalisation”, International Marketing Review, Vol. 7 No. 4, pp. 11-24.

Johanson, J. and Vahlne, J.-E. (1977), "The internationalization process of the firm - a model of knowledge development and increasing foreign market commitments", Journal of International Business Studies, Vol. 8 No. 1, pp. 23-32.

Johanson, J. and Wiedersheim-Paul, F. (1975), "The internationalization of the firm - four swedish cases”, Journal of Management Studies, Vol. 12 No. 10, pp. 305-323.

Khan, O.J. (2010), “The regionalization vs. globalization debate on internationalization: an analysis and direction for future research”, Global Partnership Management Journal, Vol. 1 Nos 1/2, pp. 25-36.

Knowler, G. (2017), “Ocean alliance provides new update of east-west network", The Journal of Commerce Online (accessed 23 Februry 2017), p. 6.

Kotler, P. and Keller, K.L. (2012), Marketing Management, 14th ed., Prentice Hall, Upper Saddle River, NJ.

Lee, C.Y. and Song, D.P. (2017), "Ocean container transport in global supply chains: overview and research opportunities”, Transportation Research Part B, Vol. 95, pp. 442-474.

Lemoine, W. and Dagnæs, L. (2003), "Globalisation strategies and business organisation of a network of logistics service providers", International Journal of Physical Distribution \& Logistics Management, Vol. 33 No. 3, pp. 209-228.
Shipping lines: examining sales network 
MABR

2,3

Levinson, M. (2006), The Box: How the Shipping Container Made the World Smaller and the World Economy Bigger, Princeton University Press, Princeton, NJ.

Lin, W.-T. (2012), "Family ownership and internationalization processes: internationalization pace, internationalization scope, and internationalization rhythm", European Management Journal, Vol. 30 No. 1, pp. 47-56.

McCalla, R., Slack, B. and Comtois, C. (2004), "Dealing with globalisation at the regional and local level: the case of contemporary containerization”, The Canadian Geographer, Vol. 48 No. 4, pp. 473-487.

Mentzer, J.T., Myers, M.B. and Cheung, M.-S. (2004), "Global market segmentation for logistics services”, Industrial Marketing Management, Vol. 33 No. 1, pp. 15-20.

Murphy, P. and Daley, J. (1996), "A preliminary analysis of the strategies of international freight forwarders”, Transportation Journal, Vol. 35, pp. 5-11.

Murphy, P., Dalenberg, D. and Daley, J. (1988), "A contemporary perspective of international port operations", Transportation Journal, Vol. 28, pp. 23-32.

Panayides, P.M. and Wiedmer, R. (2011), "Strategic alliances in container liner shipping”, Research in Transportation Economics, Vol. 32 No. 1, pp. 25-38.

Perriard, M. (1995), Towards a Measure of Globalization, University, Institute for Economic and Social Sciences University Fribourg, Fribourg.

Rugman, A.M. (2000), The End of Globalization, Random House Business, London.

Rugman, A.M. (2005), The Regional Multinationals: MNEs and "Global" Strategic Management, Cambridge University Press, Cambridge, MA.

Ryoo, D.K. and Thanopoulou, H.A. (1999), "Liner alliances in the globalization era: a strategic tool for asian container carriers", Maritime Policy \& Management, Vol. 26 No. 4, pp. 349-367.

Slack, B. and Frémont, A. (2005), "Transformation of port terminal operations: from the local to the global", Transport Reviews, Vol. 25 No. 1, pp. 117-130.

Sullivan, D. (1994), "Measuring the degree of internationalization of a firm", Journal of International Business Studies, Vol. 25 No. 2, pp. 325-342.

Welch, L.S. and Luostarinen, R. (1988), "Internationalization: evolution of a concept", Journal of General Management, Vol. 14 No. 2, pp. 34-55.

Wood, D.F. (Ed.) (2002), International Logistics, 2nd ed., AMACOM Books, New York, NY.

Xu, M., Li, Z., Yanlei, S., Xiaoling, Z. and Shufei, J. (2015), "Evolution of regional inequality in the global shipping network", Journal of Transport Geography, Vol. 44, pp. 1-12.

\section{Corresponding author}

Herbert Kotzab can be contacted at: kotzab@uni-bremen.de

For instructions on how to order reprints of this article, please visit our website:

www.emeraldgrouppublishing.com/licensing/reprints.htm

Or contact us for further details: permissions@emeraldinsight.com 